\title{
Accounting students attitudes and aspirations profiles and their performance in a subject: An Exploratory Study
}

\author{
Fábio Frezatti ${ }^{\Pi}$ \\ University of São Paulo \\ Gilberto de Andrade Martins \\ University of São Paulo \\ Geraldo Alemandro Leite Filho ${ }^{\dagger}$ \\ Unimontes
}

\begin{abstract}
The aim of this study is to establish a link between the profile of students (in terms of attitudes and aspirations) and their performance in accountancy subjects. The study analyzes perceptions of which requirements ensure a satisfactory performance in the subjects and identifies student aspirations and how students use their time. This paper describes an exploratory descriptive study using descriptive and multivariate statistical data analysis. The theoretical framework considers that the student's view is important for the evaluation processes The results show that 'professor', 'contents', 'bibliography', 'group', and 'time' provide an impact on the development of the student. They results provide useful information for teachers in positively influencing learning for their classes.
\end{abstract}

Keywords: students' performance, students' profile, accounting students.

Received in 08/12/2005; revised in 15/02/2006; accept in 30/03/2006.

Corresponding authors:

Fábio Frezatti

Doutor em Controladoria e

Contabilidade

Universidade de São Paulo

Adress: Av. Prof. Luciano Gualberto,

908 - Prédo III, Cidade Universitária,

05508900 - Sao Paulo, SP - Brasil

Email: frezatti@usp.br

Telephone: (11) 30915820
Gilberto de Andrade Martins

Doutor em Administração

Universidade de São Paulo

Adress: Av. Prof. Luciano Gualberto,

908 - Prédo III, Cidade Universitária,

05508900 - Sao Paulo, SP - Brasil

Email:

geraldo.alemandro@unimontes.br
Geraldo Alemandro Leite Filho Doutor em Administração

Universidade Estadual de Montes

Claros

Adress: Av. Rui Braga, s/n prédio 1

Campus universitário Prof. Dary

Ribeiro, Vila Mauriceia, 39400-000 -

Montes Claros, MG - Brasil

Email:

geraldo.alemandro@unimontes.br

Telephone: (38) 32167857 


\section{INTRODUCTION}

$\mathrm{E}$ valuation of school performance has been studied intensively in the field of education. Vianna (2000) has noted the following contributions to research in this area.

- Tyler (1942) posited evaluation as the process of a compared performances and predefined instruction aims.

- Stake (1967) constructed a model in which intention and objectives were related.

- Scriven (1967) posited evaluation as a data-surveying process for analysis value determination of a certain phenomenon - a position that was to influence many evaluation theoreticians.

- Stufflebeam (1971) followed Scriven's lead, developing a theoretical plan based on the idea that evaluation is aimed at decision-making - that is, that evaluation is a process that leads to a choice among various alternatives.

Although some authors (Alken and Daillak, cited by Vianna, 2000, p. 36) have affirmed there do no evidence the development of a general theory of evaluation. The contributions cited above provide some guidance. In simplistic terms, the word 'evaluation' has two different meanings (Vianna, 2000, p. 35):

- prescriptive - evaluation is conceived of, as a set of rules, prescriptions, prohibitions, and reference frameworks that specify what is good and proper for evaluation; and

- descriptive - evaluation is conceived of as a set of statements that describe, forecast, and explain evaluation activities.

Evaluation is made more complex by such factors as learning and curriculum efficiency (practical activities that assist teaching), financial and administrative factors, and the sociopolitical aspects of education. A full discussion of the subject is beyond the scope of this paper. However, for the purpose of this present study, the premise is that any evaluation of the educational standards achieved by students must start from an analysis of the factors not directly associated with the school that affect education for more also inlude an analysis of the school's actions in terms of input, process, and product.

Understanding student performance is a challenge for teachers and educational institutions. Evaluation is an essential task which is not always understood and not easy to execute. It is an important element of any pedagogical project/course because it measures students' course performance and, consequently, also identifies how the measures up to market expectations. Much is said about this relationship to accountancy courses in Brazil. However, because of their heterogeneity, such evaluation is relatively scarce, and that which is done does not focus on the particularities of the course itself.

With respect to educational evaluation, Vianna (2000) opines that, to evaluate educational quality, it is necessary to examine factors not directly associated with the school. These include, among others, socio-economic family status, parents' educational level, educational resources at home, parent interest and participation in the educational process, educational activities outside school, leisure and social activities (television, sports and group integration, and student attitudes and ambitions.

Drawing on Vianna (2000), the following observations can be about these matters.

- There is a likely association between evaluation and factors external to the school. Such external elements accepted because they integrate the individual and society.

- On the set of elements quoted above, the author's focus is on an analysis of student attitudes and ambitions due criticism of this view is that it can be subjective. To overcome this criticism, with respect to the question of student attitude, this study 
assesses student performance in a subject by assessing their use of time-thus revealing student priorities. With respect to student ambitions, an evaluation of students' motives in choosing a course.

The research question for the study can therefore be expressed in the following terms:

Are students attitudes and ambitions related to their performance in subjects of an accountancy subject?

The premise of this study is the belief that if students are better understood, individual or institutional guidance can be offered to improve with a view to achieving a favorable performance, thus achieving better use of resources and better educational outcomes.

\section{THE LABOR MARKET AND ACCOUNTANCY EDUCATION}

Accounting education in Brazil offers many career opportunities. The labor market is very broad (Marion 2001). Professionals can choose financial accounting, cost or management accounting, and controllership. They can become public accountants in practice auditors (independent or internal) and accounting experts, researchers, or teachers-quite apart from functioning in the public sector in autonomous governmental institutions and other direct and indirect administrative functions.

Globalization and technological advances now mean that organizations require better preparation, contextualized, and multidisciplinary graduated. Thusstudents must to adapt and show interactive, be economically, socially aware and be able to work without supervision.

According to the Brazilian Ministry of Education and Culture (MEC 2002), there are 700 undergraduate accountancy courses in Brazil. On average 15,000 new graduates enter the job. However, only nine courses offer a master's degree in accountancy, and an average of 180 new master's graduates comes to the market each year. In addition, in the country, there is one $\mathrm{PhD}$ course, which graduates about 12 doctorates each year.

The MEC (2002) allows accountancy educational institutions to define professional profiles, and to determine how they can be achieved. However, because this profile has develop created uncertainties among teachers responsible for defining the subjects. Subjects are not always coordinated, logical, and consistent a strategy that can produce repetitive teaching. This means at the end of the course, the students are expected to have acquired the necessary competencies for pursuing their chosen profession.

According to Tavares (2002), accounting educators includes the following concepts: education, teaching, formation, learning, and evaluation.

- Education is a social process by means of which society integrates its new members through the transmission of values, rules, and behavioral standards.

- Teaching is a more specific educational activity, associated with a school or university that is directed towards the appropriation of specific knowledge.

- Formation is the individual process of 'humanization', whereby a student's critical, creative, and motivating abilities as a person are developed.

- Learning is the cognitive process by means of which the person acquires knowledge and becomes capable of interacting with the world.

- Evaluation is an analytical dimension of the teaching-learning process.

Accounting professionals must to add value to an organization being socially responsible, act ethically, be competent and trustworthy (Pereira and Leite Filho, 2002). In a knowledge society, accountancy teaching is adopting an interactive model in which educators and students act as participants in a broad teaching-learning process that produces and disseminates accounting knowledge. Accountancy teaching must therefore provide innovative, logical, critical action plans that create new perspectives on the world and that encourage 
students to develop new strategies and thinking in their personal, cultural, and professional lives. According to Resolution 04/97 of the Ministry of Education and Culture, accountancy courses must provide conditions to students obtain the following abilities and competencies:

- the ability to use accounting language in accordance with the approach of communication theory;

- a systemic, holistic, and interdisciplinary view of accounting activities;

- the use of logical, critical, and analytical thinking for problem-solving;

- the elaboration of reports that contribute to the effective performance of accounting information users; and

- the articulation, motivation, and leadership of multidisciplinary teams for obtaining data and for creating and disseminating accounting information.

Moreover, according to the above-mentioned resolution, $50 \%$ of the total time in accountancy courses must be committed to content that relates to basic and professional formation. This content includes administration, economics, law, quantitative methods, accounting theory, financial accounting, tax accounting, management accounting, auditing, and controllership. In establishing a curriculum for accountancy courses, teaching institutions are free to consider local and regional peculiarities in choosing an appropriate emphasis for the desired graduate profile - as long as they adhere to the requirement to devote $50 \%$ of total time to basic and professional formation (as described above). This allows 50\% of teaching time to be committed to particular local curriculum emphasis.

\section{METHODOLOGY}

This is an exploratory and descriptive study of one accounting class group (see Table 1). Students were surveyed when classes began, and them evaluated during the school year. Students were informed that the initial questionnaire was not compulsory and that it should be completed and returned only if they agreed to participate in the research. As shown in Table 1 indicated, $65 \%$ of students completed and returned the questionnaire.

Table 1. Sample Composition.

\begin{tabular}{lc} 
& Description \\
\hline Date & $2^{\text {nd }}$ semester 2002 \\
Period & Night \\
Number of students in class & 58 \\
Number of respondents & 38 \\
$\%$ of respondents/class & 65 \\
$\%$ male & 50 \\
$\%$ female & 50 \\
\hline
\end{tabular}


Table 2 shows the learning evaluation modes developed during the semester.

Table 2. Evaluation Modes

\begin{tabular}{cccc}
\hline Description & Weight & Times applied & Measure \\
\hline Tests & $30 \%$ of total grade & $10 /$ student/semester & Individual \\
Project presentation & $30 \%$ of total grade & $1 /$ group/semester & Group \\
Final exam & $40 \%$ of total grade & $1 /$ student/semester & Individual \\
\hline
\end{tabular}

The evaluation method used during the semester were tests, examinations, and projects (Gil 1997). Tests consisted of eight multiple-alternative questions. Projects involved the development of a budget for a fictitious entity; which was then presented in class by groups of students. Written examinations were conducted at the end of the course. Average grades obtained by participants are presented in Table 3 .

Table 3. Grades Attributed during Evaluation

\begin{tabular}{lc|c|c|c}
\hline \multicolumn{1}{c}{ Description } & \multicolumn{2}{c}{ Grades } & \multicolumn{2}{c}{ Class Attendances } \\
& $\begin{array}{c}\text { Maximum } \\
\text { Grades } \\
\text { Possible }\end{array}$ & $\begin{array}{c}\text { Observed } \\
\text { Average }\end{array}$ & $\begin{array}{c}\text { Maximum } \\
\text { Percentage } \\
\text { Possible }\end{array}$ & Observed \\
\cline { 2 - 5 } Tests & 3.0 & 1.88 & NA & NA \\
Project presentation & 3.0 & 2.61 & NA & NA \\
Final exam & 4.0 & 1.94 & NA & NA \\
Total & 10.0 & 6.43 & $100.0 \%$ & $87.1 \%$ \\
\hline
\end{tabular}

There were significant differences between the maximum possible grades and the grades actually obtained. The largest differences of these grades occurred in the final examination grade.

\subsection{Treated variables}

Various factors not directly related to a school can influence the educational process (Vianna 2000). These factors were grouped according to: (1) students perception of satisfactory performance in the subject; (2) how students use their time; and (3i) the reason for choosing the course (see Table 4). Variables were measured using an interval scale and multivariate statistical techniques for data treatment. 
Table 4. Elements $x$ Variables $x$ Scale

\begin{tabular}{lll}
\hline \multicolumn{1}{c}{ Critical elements } & \multicolumn{1}{c}{ Variables to be treated } & \multicolumn{1}{c}{ Scale } \\
\hline What does success in the & On the teacher & Likert Scale with semantic \\
subject depend on? & & opposites (from 1 to 5): \\
& Totally agree $=\mathbf{1}$ \\
& Partially agree $=\mathbf{2}$ \\
& Indifferent $=\mathbf{3}$ \\
& Partially Disagree $=\mathbf{4}$ \\
& Totally Disagree $=\mathbf{5}$ \\
\hline
\end{tabular}

On the subject contents

On the time the subject is administered

On the subject bibliography

On the class

On my group

On me

Others

\begin{tabular}{|c|c|c|}
\hline How do they use their time? & Work in an organization & $\begin{array}{l}\text { Interval scale, from } \mathbf{0} \text { to } 8 \\
\text { hours/day, on the average }\end{array}$ \\
\hline & $\begin{array}{l}\text { Training in an organization } \\
\text { Study course subjects } \\
\text { Study (other things that are not part of the } \\
\text { course) } \\
\text { Leisure } \\
\text { Taking care of somebody } \\
\text { Voluntary work } \\
\text { Traffic } \\
\text { Others }\end{array}$ & \\
\hline $\begin{array}{l}\text { Why are you taking the } \\
\text { course? }\end{array}$ & It is the profession I have chosen & $\begin{array}{l}\text { Likert Scale with semantic } \\
\text { opposites (from } 1 \text { to 5): } \\
\text { Totally agree } \\
\text { Partially agree } \\
\text { Indifferent } \\
\text { Partially Disagree } \\
\text { Totally Disagree }\end{array}$ \\
\hline & $\begin{array}{l}\text { I do not know for sure } \\
\text { I was not approved in the course I wanted } \\
\text { to take } \\
\text { If I could start again, I would chose the } \\
\text { same course } \\
\text { There are accountants in my family } \\
\text { My family urged me to choose this course } \\
\text { The course is easy } \\
\text { Employment chances are high } \\
\text { Stable career } \\
\text { Others }\end{array}$ & \\
\hline
\end{tabular}

\subsection{Descriptive and multivariate statistics}

The statistical treatment was developed using the clusters shown in Table 4. In establishing these clusters, an hierarchical approach was chosen, considering the most distant neighbor, on the basis of a method that considers the Euclidean distance square in terms of interval. The definition of three clusters took the differentiation perspective into account by 
the quantity of respondents, which gave rise to differentiation in data treatment. With a view to validating the sample variables, before obtaining the clusters, Cronbach's alpha technique was applied and a 0.59 validity was obtained, which is considered reasonable for exploratory research (Hair et al. 1998).

\section{RESULTS}

\subsection{Students' perceptions of what is relevant for satisfactory performance.}

Table 5. Perception of what is Important for Satisfactory Performance

\begin{tabular}{|l|c|r|r|r|}
\hline & Cluster 1 & Cluster 2 & Cluster 3 & Mean \\
\hline Variables: & & & & \\
Teacher & 4,67 & 3,58 & 4,25 & 3,74 \\
Contents & 3,33 & 3,68 & 4,50 & 3,74 \\
Time & 1,00 & 2,84 & 3,75 & 2,79 \\
Bibliography & 2,67 & 3,94 & 4,00 & 3,84 \\
Class & 1,00 & 2,90 & 3,50 & 2,82 \\
My group & - & 3,58 & 4,00 & 3,34 \\
Me & - & 3,65 & 4,50 & 3,45 \\
Other & 3,33 & 4,77 & 5,00 & 4,68 \\
& & & & \\
Descriptive Statistics: & & & & \\
Mean & 2,00 & 3,62 & 4,19 & 3,55 \\
Standard deviation & 0,65 & 0,69 & 0,33 & 0,82 \\
Minimum & 1,25 & 2,00 & 3,75 & 1,25 \\
Maximum & 2,38 & 4,63 & 4,50 & 4,63 \\
\hline
\end{tabular}

The highest mean values were observed with respect to 'professor', 'contents', 'bibliography', and 'me'. The item 'others' had the highest mean value, although it is composed of various aspects that are difficult to define.

The findings terms are summarized in the clusters below.

Cluster 1: Students felt that they were dependent on the teacher, and mean value range was 4.67 with a maximum of 5.0. In contrast, answers for 'own group' and 'self' produced a mean value of zero, which was unexpected. In other words, this group expected everything from the teacher-perhaps indicating of immaturity in relation to the course.

Cluster 2: Results were neutral. The highest mean value was the dependence 'bibliography' (3.94 with a maximum of 5.0), which was exceeded only by the response given for 'others'.

Cluster 3: All variables had higher mean values than the other clusters, except for 'the teacher' variable, although significant, did not exceed the mean value obtained in cluster 1 . Mean values for dependence 'on me' and 'on contents' (4.5 with a maximum of 5.0) were higher than for the others, except for dependence 'on others'. This group was apparently more mature (in terms of what to expect from it) than other groups, the members had balanced expectations with respect to the different elements.

\subsection{Respondents' attitudes, measured by the answers given about time use.}

\section{Table 6. How the Student Uses Time}




\begin{tabular}{|lr|r|r|r|}
\hline & Cluster 1 & Cluster 2 & Cluster 3 & Mean \\
\hline Variables: & & & & \\
Work & 2,50 & 3,69 & 4,67 & 3,71 \\
Traineeship & 4,67 & 2,92 & 1,00 & 3,04 \\
Studying the subject & 2,00 & 2,04 & 2,00 & 2,03 \\
Study & 1,33 & 1,93 & 2,00 & 1,88 \\
Leisure & 1,00 & 1,59 & 1,50 & 1,53 \\
Taking care of somebody & 1,33 & 1,15 & 1,50 & 1,19 \\
Volunteer & 1,00 & 1,23 & 1,00 & 1,19 \\
Traffic & 2,33 & 2,03 & 2,00 & 2,06 \\
& & & & \\
Descriptive statistics: & & & & \\
Mean & 2,00 & 2,10 & 2,75 & 2,17 \\
Standard deviation & 0,13 & 0,37 & 1,50 & 0,58 \\
Minimum & 1,88 & 1,63 & 2,00 & 1,63 \\
Maximum & 2,13 & 3,50 & 5,00 & 5,00 \\
\hline
\end{tabular}

'Work' and 'traineeship' provided the highest mean value.

Cluster 1: 'Traineeship' (mean value 4.67, with a maximum of 5.0) gave the the highest response. Time spent in 'traffic' was different from the other variables, although the mean value was low (2.33 with a maximum of 5.0).

Cluster 2: Results were neutral .Various mean values were significant in absolute terms: 'work' (3.69 with a maximum of 5.0), 'traineeship' (2.92 with a maximum of 5.0), and 'studying the subject' (2.04 with a maximum of 5.0). Perhaps this group dedicated less time to work/traineeship activities, with more time being available for other activities.

Cluster 3: Corresponds to the group that predominantly 'has jobs' working in companies and having professional experience (mean value 4.67 with a maximum of 5.0). The variable 'taking care of somebody' provided the highest mean value ( 1.5 with a maximum of 5.0). The cluster in which most time is applied to work also contained the highest mean value for time dedicated to other persons.

\subsection{Student ambitions, measured by the answers in which the student advised the reason for choosing the course.}


Table 7. Reasons for Choosing the Course

\begin{tabular}{|lrrrrr|}
\hline & Cluster 1 & Cluster 2 & Cluster 3 & Mean \\
\hline Variables: & & & & \\
Chose & 5,00 & 4,26 & 3,50 & 4,24 \\
Does not know & 1,00 & 1,39 & 0,50 & 1,26 \\
Did not manage & 1,33 & 1,35 & 0,25 & 1,24 \\
Would choose again & 3,33 & 4,13 & - & 3,63 \\
Family & 0,67 & 2,06 & 0,25 & 1,76 \\
Family pressure & 0,67 & 1,26 & 0,50 & 1,13 \\
Easy & 0,33 & 2,03 & 1,00 & 1,79 \\
Facility to find work & 4,33 & 3,71 & 1,00 & 3,47 \\
Stable career & 2,33 & 3,32 & - & 2,89 \\
& & & & \\
Descriptive statistics: & & & & \\
Mean & 2,11 & 2,61 & 0,78 & 2,38 \\
Standard deviation & 0,87 & 0,41 & 0,86 & 0,75 \\
Minimum & 1,11 & 1,78 & 0,00 & 0,00 \\
Maximum & 2,67 & 3,44 & 2,00 & 3,44 \\
\hline
\end{tabular}

Highest mean values were 'chose', 'would choose again', and facility to find 'work'.

Cluster 1: Members took the course because they 'chose' it (mean value 5.0 with a maximum of 5.0). In the answer about the possibility of choosing another course, the alternative 'would choose again' (the accountancy course) was significant (3.33 for a total of 5.0) but not higher than in cluster 2. In comparing 'chose' with 'would choose again', it can be inferred that a certain regret occurred (3.33 for a total of 5.0). Finally, they considered that the profession provided 'jobs' easily (4.33). For a group in which students are mainly trainees, worries about finding a good job prevail.

Cluster 2: In comparison with the other clusters, highest mean values were concentrated in 'would chose again' (4.13 for a total of 5.0), 'there are other accountants in the family' (2.06 for a total of 5.0), consider the course 'easy' (2.03 for a total of 5.0), and that it is easy to find 'work' (3.71 for a total of 5.0). This cluster displayed a high mean value for the variable 'would choose again', which might indicate students' satisfaction with the course they chose.

Cluster 3: None of the mean values stood out in this group in relation to the other clusters. The item 'chose' obtained the lowest mean value (3.5 for a total of 5.0). In contrast, this cluster had the lowest mean values for 'does not know for sure' ( 0.5 for a total of 5.0), 'did not manage to pass in the desired course' ( 0.25 for a total of 5.0), 'would choose again' (zero mean value), 'there are accountants in the family' ( 0.25 for a total of 5.0), and 'family pressure' $(0.50$ for a total of 5.0). This group apparently demonstrated a more mature and confident approach — even if its members would not choose the same course again.

\section{SUBJECT EVALUATION ACCORDING TO CLUSTERS}

The cluster identification structure considered elements and variables and ignored students' grades. After combining these clusters with grades at a later stage:

- cluster 1 provided the lowest mean values for grades and frequency; and

- cluster 3 provided the highest mean values for grades andfrequency. 
Table 8. Grade and Frequency Distribution per Cluster

\begin{tabular}{|c|c|c|c|c|c|c|}
\hline & \multirow[b]{2}{*}{ Qty students } & \multicolumn{4}{|c|}{ Evaluation } & \multirow{2}{*}{$\begin{array}{l}\% \text { Freq. } \\
\text { in subject }\end{array}$} \\
\hline & & Tests & Project & Final exam & Total & \\
\hline Cluster 1 & 3 & 1,24 & 2,60 & 1,13 & 4,97 & $58,7 \%$ \\
\hline Cluster 2 & 31 & 1,91 & 2,61 & 1,99 & 6,51 & $89,5 \%$ \\
\hline Cluster 3 & 4 & 2,11 & 2,65 & 2,10 & 6,86 & $89,3 \%$ \\
\hline Mean & & 1,88 & 2,61 & 1,94 & 6,43 & $87,1 \%$ \\
\hline Total & 38 & & & & & \\
\hline Maximum & & 2,63 & 2,70 & 3,40 & 8,45 & 97,00 \\
\hline Minimum & & 0,23 & 1,70 & - & 2,90 & - \\
\hline
\end{tabular}

Subject evaluations as identified by each of the analyzed cluster components are presented in Table 8.

Cluster 1: This cluster had the lowest mean value for total grades (4.97 for a total of $10.0)$. The group was small, $(3 / 38=7.9 \%)$ with similar mean values for tests and final examination. Group grades for the projects did not demonstrate any difference in knowledge for any of the groups. The average class frequency was the lowest among all groups (58.7\% for a total of $100 \%$ ). Considering that this group believed that satisfactory performance results from the 'teacher' and that there was not any significant dependence on the 'group' and 'self', perception and evaluation results might be associated. Although this group studied at night, members were mainly 'trainees'. They stated that they were taking the course because they chose it and would choose it again if possible.

Cluster 2: This cluster had the highest mean value for total grades (6.51 for a total of $10.0)$. It was the biggest class group $(31 / 38=81.6 \%)$, which did not stand out during tests and final examinations, although a high mean value was obtained for project. Class frequency was high and very similar to that in cluster $3(89.5 \%$ for a total of $100 \%)$.

Cluster 3: Like the first cluster, this group was small $(4 / 38=10.5 \%)$ and stood out for all grades, with a frequency similar to that of cluster 2. All variables displayed highest mean values, except for 'teacher'. This might indicate that these students did not expect too much from the teachers; rather, they take into account all the various elements of the subject. Most of the members of this group work, and nothing stands out in relation to the reason for choosing the course.

\section{CONCLUSION}

The research question that directed this research was: Are student profiles in terms of attitudes and ambitions associated with performance in the subjects of an accountancy course? The research demonstrated that this is true, although it is difficult to generalize the conclusions in view of the non-probabilistic and guided sample. The following findings are of particular interest.

- Cluster distributions show that few students received high grades as measured by high and low mean values. Howevergiven more observations, it is expected that the curve would tend to normal.

- Clusters provided alternative profiles of cause elements according to student perception . These profiles were attached to performance and, at the limits, they demonstrated that low evaluation grades attached to students who did not attend class Other students groups participated in about $58.7 \%$ of classes. These students identified teacher as the subject and considered that satisfactory subject performance 
is independent from the teacher and the group they belong to. These comments apply to cluster 1 .

- Cluster 2 results deserve special attention. This cluster had most of participants. While no mean values exceeded those for the other clusters. They were relevant in terms of magnitude, which indicates that theyperceived these variables as significant, but to a lesser extent than in the other clusters. With respect to time, although cluster 1 contained mainly trainee participants and cluster 3 consisted mainly of working participants, cluster 2 contained a significant number of participants from both groups. In relation to the opportunity to choose a course again, choosing the accountancy course stood out in relation to other options - indicating that students believed that they made a good choice.

- Highest grades and class frequency figures were found in cluster 3, a group that was characterized by maturity and effort. This group was relatively integrated and spent a reasonable part of its time working or dedicating time to others. Members perceived all variables as important for satisfactory subject performance and did not expect everything from one single variable.

Future research could study student profiles with a view to providing a customized approach to increase students' chances of success. A greater emphasis on defining expectations at the beginning of the course, as well as a broader discussion about the subject, could influence student motivations and provide the necessary conditions for different perceptions and attitudes.

Increasing the number of samples and identifying additional variables could contribute to improvements on this study and the combination of different environments and compositions could also be of value.

\section{REFERENCES}

ALMEIDA, M. D. 2000. Currículo como artefato social. Natal, Editora UFRN.

GARVIN, D. A., SWEET, A.1991. Education for Judgment: the artistry of discussion leadership, Boston, Harvard Business School Press

GIL, A. C.1997. Metodologia do ensino superior, $3^{\text {rd }}$ edition, São Paulo, Atlas.

HADJI, C.2001. Avaliação desmistificada. Porto Alegre, Artmed.

HAIR Jr, J., A., ROLPH E., TATHAM, R. L. and BLACK, William C.1995. Multivariate data analysis. Upper Saddle River, Prentice Hall, fifth edition.

KRASILCHIK, M.1998. Planejamento educacional: estruturando o currículo. São Paulo, Educação Médica Sarvier.

LAKATOS, E. M., MARCONI, M. de A. 2003. Fundamentos de Metodologia Científica. $5^{\text {th }}$ Ed. São Paulo, Atlas.

MARION, J. C.2001. O ensino da Contabilidade, $2^{\text {nd }}$ edition, São Paulo, Atlas.

Ministério da Educação e Cultura, MEC. Parecer CNE/CES 146/2002.

Ministério da Educação e Cultura, MEC. Resolução 04/97 e 03/92.

MOREIRA, A. F. B.2001. O currículo de graduação hoje: possibilidades e desafios. In: II Fórum de graduação da UNIMONTES. 
PEREIRA, J. C. R.2001. Análise de dados qualitativos: estratégias metodológicas para as ciências da saúde, humanas e sociais, São Paulo, EDUSP.

PEREIRA, E. S., LEITE FILHO, G. A. 2002. A influência do marketing no perfil do profissional contábil. Revista Pensar Contábil, CRCRJ, No. 15, p.26-30

TAVARES, M. R. 2001. Paradigmas Avaliativos e o ensino de graduação. In: II Fórum de Graduação. UNIMONTES.

VEIGA, I. P. A., CARDOSO, M. H. F. 1991. Escola fundamental, currículo e ensino, Campinas, Papirus.

VIANNA, H. M. 2000. Avaliação educacional, São Paulo, IBRASA. 